\title{
The Two-Way Language Bridge: Co-Constructing Bilingual Language Learning Opportunities
}

\author{
MELINDA MARTIN-BELTRÁN \\ University of Maryland \\ College of Education \\ 2311 Benjamin Building \\ College Park, MD 20742 \\ Email: memb@umd.edu
}

\begin{abstract}
Using a sociocultural theoretical lens, this study examines the nature of student interactions in a dual immersion school to analyze affordances for bilingual language learning, language exchange, and co-construction of language expertise. This article focuses on data from audioand video-recorded interactions of fifth-grade students engaged in joint writing activities (in Spanish and English). A qualitative analysis of discourse found that students seized opportunities to use two languages simultaneously, which multiplied opportunities for metalinguistic analysis and bridged understanding across interlocutors. Findings suggest that language learning affordances could be fostered in linguistically diverse classrooms by allowing interplay between languages and by creating activities that encourage learners to co-construct text. This study contributes to the expansion and reconceptualization of the field of language education research by attending to bilingual language learners, or first language/second language users, whose reciprocal language learning experiences show how concepts from the fields of second language acquisition and bilingualism are necessarily linked. This study also contributes to language learning research using a sociocultural perspective by revealing the ways that two languages can simultaneously become mediational tools and objects of analyses within bilingual interactional spaces.
\end{abstract}

DUAL IMMERSION EDUCATION AIMS TO increase language learning affordances for both minority-language ${ }^{1}$ students and majoritylanguage students by offering a space where learners are encouraged to draw on two or more languages as academic resources. Dual immersion program design is built on the assumption that interaction between learners is central to the learning process, yet we know surprisingly little about how or whether the students interact meaningfully (Genesee, 1985; Saunders \& O'Brien, 2006; Valdés, 1997). Several studies have confirmed the success of dual immersion programs with

The Modern Language Journal, 94, ii, (2010) 0026-7902/10/254-277 \$1.50/0 (C2010 The Modern Language Journal measures of high academic achievement (Alanis, 2000; Christian, Howard, \& Loeb, 2000; de Jong, 2002; Lindholm-Leary, 2001, 2004; Thomas \& Collier, 2002), yet there is less research about the everyday interactions between language learners and classroom contexts, which may lead to successful language learning and academic achievement. As Hayes (2005) has shown, many studies and reports have focused on program design (the "recipe approach," p. 93) rather than the dialogic processes of language learning at work in the school. Angelova, Gunawardena, and Volk (2006) have begun to build this body of research by describing strategies students used during peerteaching. The findings from the present study corroborate findings from the Angelova et al. study and go beyond to more closely analyze student interactions as collaborative dialogue in which we can observe "microgenesis" (Lantolf, 2001; 
Vygotsky, 1978) or processes of language learning unfolding during the interactions.

Recent studies (Fitts, 2006; Hayes, 2005; Lee, Bonnet-Hill, \& Gillespie, 2008) have documented the challenges dual immersion programs face and suggested that programs often foster "parallel monolingualism" instead of bilingualism. This separation of language acquisition processes in instructional design reflects the theoretical divide in second language acquisition (SLA) research, which has often conceptualized first language (L1) and second language (L2) acquisition as separate and sequential rather than examining continuous bilingual language development. These studies call for further research to understand how to create bilingual interactional spaces that offer a rich context for language learning. The present study responds to this need for more research by focusing on moments when bilingual interactional spaces are successfully created, which may increase language learning affordances for students with a wide range of language experiences. The purpose of this study was to examine the nature of student interactions using a sociocultural lens to analyze potential opportunities for language learning, language exchange (across Spanish and English), and creative coconstruction of language expertise.

\section{THEORETICAL FRAMEWORK}

Dual immersion program design draws from theoretical and empirical work in SLA, which has developed the input-interaction-output (IIO) model for language learning (see Block, 2003; Gass \& Selinker, 2001; Long, 1996; Mackey, 2007). This model explains that interaction between L2 learners and "native speakers" (as well as interaction between learners) promotes language learning through negotiation for meaning, modified, comprehensible input, and opportunities for learners to produce language and test new output hypotheses (Gass, 1997; Hatch, 1992; Long, 1996; Long \& Porter, 1985; Mackey, 2007; Mackey, Gass, \& McDonough, 2000; Pica, 1994; Swain, 1985). Several empirical studies (see review in Mackey, 2007) have found a positive relationship between opportunities for learners to interact and language development (Keck, Iberri-Shea, Tracy-Ventura, \& Wa-Mbaleka, 2006). Cognitive or computational models of SLA view input and interaction as activating individual, self-contained psycholinguistic processes (Ellis, 2005), whereas a sociocultural theory of the mind is primarily concerned with distributed cognition and conscious- ness as mediated through social interaction and cultural artifacts.

This study employs a sociocultural conceptual framework, which shifts the focus from the individual learner to the social activity of learning, particularly in dialogic interaction. This study builds on research (Anton \& DiCamilla, 1998; Donato \& Lantolf, 1990; Foster \& Ohta, 2005; Lantolf, 2000; Storch \& Wigglesworth, 2003; Swain, 2000, 2006; Swain, Brooks, \& Tocalli-Beller, 2002; Swain \& Lapkin, 1998; van Lier, 2000) employing a sociocultural theoretical framework influenced by the work of Vygotsky (1978), which provides a lens to understand microprocesses of language learning in action that have often gone unexamined. Swain et al. have argued that peer-peer interaction fosters language learning and that a microgenetic analysis (analysis of moment-to-moment communication) will help us to better understand how learners can create further language learning affordances (van Lier, 2000).

I draw from research examining collaborative dialogue (Swain, 2000; Swain \& Lapkin, 2000) as an important window to understand how learners work together to solve linguistic problems and co-construct knowledge about language. I found the language-related episode (LRE) —as a unit of analysis that describes a specific kind of collaborative dialogue-to be helpful both theoretically and methodologically. Swain and Lapkin (1998) defined an LRE as "any part of a dialogue where the students talk about the language they are producing, question their language use, or correct themselves or others" (p. 326). My study built on this description of LREs informed by other studies (Foster \& Ohta, 2005; Lapkin, Swain, \& Smith, 2002; Mackey 2007; Mayo, 2002; Swain \& Lapkin, 2002) to further investigate interactions between young students and the practices that afford and/or constrain learning opportunities in a dual-language setting.

Recently, scholars have shown how the analysis of LREs can link cognitive and sociocultural aspects of language learning (Foster \& Ohta, 2005; Tocalli-Beller \& Swain, 2007). They argue that LREs capture more than moments of negotiation for meaning (which are often about breakdowns in communication) by shedding light on sociocultural dimensions of communication successes, innovations, and co-construction of language in interactions. Extending this work, Swain (2006) coined the term languaging to describe the way that learners use speaking and writing to mediate cognitively complex activities. "Through languaging-a crucial mediating psychological and cultural activity-learners 
articulate and transform their thinking into an artifactual form, and in doing so, make it available as a source of further reflection" (Swain \& Deters, 2007 , p. 822). Data from the present study found several examples of young students involved in languaging.

\section{BROADENING THE CONCEPTUAL FRAMEWORK BEYOND ONE-WAY LANGUAGE LEARNING}

Much of the interaction research in SLA from both cognitive and sociocultural perspectives has focused on one-way language learning contexts rather than bilingual or two-way language learning contexts (for a review, see Mackey, 2007 and Swain et al., 2002). Scholars such as Potowski (2004) and Valdés (1997) explain how the rationale for dual immersion programs draws from research in one-way contexts, which does not capture the complexity of dual-language schools that include heritage language speakers and a diverse group of L2 learners/users. The present study responds to Valdés's (2005) call for a reconceptualization and expansion of the field of SLA by including bilingual, heritage language students (for whom the concepts of L1, L2, and native speaker are problematic) and by examining language learning in an educational context that involves several types of language development.

Although there is a growing body of empirical studies that have been carried out in dual immersion programs (for reviews of the literature, see Howard \& Sugarman, 2007; Howard, Sugarman, \& Christian, 2003), the theoretical framework underlying these studies and program design is derived from SLA research that has focused on the acquisition of one target language. Rather than recognize multilingual contributions to interactions, research analyses have been rooted in monolingual assumptions prevalent in much SLA literature that conceptualize L1 and L2 as separate and sequential rather than continuous (for critiques of monolingual bias, see Block, 2003; Canagarajah, 2007; V. Cook, 1999, 2001; Levine, 2003; Motha, 2006; Pavlenko, 2000). The conceptual framework of this study considers continuous, simultaneous and reciprocal affordances for language learning during interactions between L1/L2 users. ${ }^{3}$

The present study seeks to link research in SLA with work done in bilingual settings in which all participants are developing multilingual repertoires and may draw on these multiple linguistic resources within a shared interactional space. Within studies of bilingualism (Heller, 1999;
Romaine, 1996; Valdés, 2003; Wei, 2000; Zentella, 1997), scholars have recognized the complexity of multilingual speakers who use a multitude of language varieties that are not separate and discreet; however, this is rarely recognized within SLA research (for exceptions, see Harris, 1999; Leung, Harris, \& Rampton, 1997).

Although many studies recognize the importance of students' other languages and have pushed the field forward to consider the use of the $\mathrm{L}^{4}$ in L2 instruction (Anton \& DiCamilla, 1998; Brooks \& Donato, 1994; Centeno-Cortés \& Jiménez, 2004; Scott \& de la Fuente, 2008; Storch \& Wigglesworth, 2003; Swain \& Lapkin, 1998), these studies have analyzed the functions of the L1 in service of learning the L2. In other words, L2 learning is the end goal (or object) and the L1 is considered separately as a mediational tool. This study broadens this research by considering ways that two languages can go back and forth symbiotically as mediational tools and objects of analysis within the same interaction.

\section{SCHOOL CONTEXT}

This study took place in at the Escuela Unida, ${ }^{5}$ a dual immersion bilingual school located in an agricultural region in central California. As a public charter school whose enrollment was open to students beyond the local neighborhood, Escuela Unida brought together students who might otherwise have little contact with each other, due to housing segregation within the school district (that followed linguistic, ethnic, and socioeconomic lines). The student body was $90 \%$ Latino (including recent immigrants and U.S.-born children), $10 \%$ white and mixed heritage students, 75\% English language learners, and 87\% receiving reduced or free lunch. The school used a 90/10 dual-language program whereby students began with $90 \%$ of their instruction in Spanish in kindergarten and reached a 50/50 balance in Spanish and English instruction by the fifth grade.

For this study, I chose to focus on one group of 30 fifth-grade students who represented a wide range of language experiences (from emergent to proficient bilinguals). In this class, there were 3 newcomers from Mexico (who arrived to the United States in the fourth and fifth grade), 20 bilingual children (or heritage language speakers) who used mostly Spanish with parents and varying degrees of English at home, and 7 children who came from homes in which they spoke primarily in English. This class had three teachers-two Spanish-model teachers in the morning and an English-model teacher in the 
afternoon. Each teacher had more than 7 years of experience and demonstrated great commitment to the bilingual program and enthusiasm in their teaching. They were cooperative partners open to reflecting on their teaching and discussing new ideas for their classroom.

\section{RESEARCH METHODS}

\section{Data Collection}

The research methodologies that guided the data collection for this project were modeled after ethnographic and sociolinguistic studies that include participant observation, interviews, and audio recordings of classroom discourse (Freeman, 1998; Valdés, 2001; Zentella, 1997). Following guidelines for interpretive inquiry, ethnography, and participant observation (Creswell, 2007; Emerson, Fretz, \& Shaw, 1995; Erickson, 1998; Hammersley \& Atkinson, 1995; Miles \& Huberman, 1994), my fieldwork included intensive longterm participation in the school, careful recording and documentation (field notes, observation protocols, analysis memos, questionnaires, student work, digital audio and video recordings), and an analytical reflection about the documentary record during the data collection process. I visited the school two to three times a week over the academic year (August-June). In addition to classroom, lunchtime, and recess observations, I observed school meetings, parent forums, parentteacher conferences, after-school programs, and district school board meetings in order to explore the school conditions and social contexts that supported or constrained opportunities for two-way language learning. To triangulate my observations, I interviewed and surveyed students, teachers, parents, and the principal about language use in and out of the school, as well as their perception of good language helpers and social groups. During class activities that required peer interaction, I placed audio recorders on students' desks supplemented by a video camera in the corner of the room while taking detailed field notes. In the subsequent description, I will focus on data from audio and video recordings during a joint writing activity.

\section{Description of Joint Activity}

This classroom was not without its challenges (see discussion in Martin-Beltrán, 2006); however, I observed several occasions when students were successfully engaged in language exchange, collaborative dialogue, and languaging (Swain,
2006). From my classroom observations and preliminary analysis of the audio recordings of interactive activities, I identified activities that promoted the most LREs. I found the most LREs during activities that involved the creation and revision of written text. I sought to build on the LRErich peer interactions during writing revisions to create activities that involved collaborative writing in both Spanish and English. My focus on writing activities was guided by the theoretical claim that writing allows learners time to monitor (Krashen, 1985) and reflect on their language production and may be a tool for co-construction of knowledge (Haneda \& Wells, 2000; Wells, 1999). Storch (2002, 2008) suggested that one way to encourage metatalk about language is to require joint written output and reflection of the language produced. To increase interdependence and collaboration, Cohen (1994) recommended that groups work on a common written product; thus, the students were instructed to write a shared letter authored collaboratively. Drawing from suggestions in Cohen's review, the teacher and I modeled collaborative writing, practiced metatalk about language with students, and provided self-evaluation and teacher-evaluation rubrics with specific collaboration criteria so that the students understood that collaborative behaviors were an important part of this assignment. In my discussions with the teachers to create activities, we struggled with ways to design equitable, collaborative writing projects that might offer shared language learning affordances. Despite our efforts to guide and model collaboration, there were varying degrees of mutuality and equality (see Storch, 2002) among the pairs.

In her study that demonstrated the importance of the collaborative nature of peer interactions, Storch (2002) identified patterns of interaction in terms of equality (control over the task) and mutuality (engagements with partner's contributions). I found Storch's descriptive categories to be helpful as I examined student interactions and considered ways that students engaged with each other's ideas, shared (or assumed) control over the direction of the task, and made shared (or unilateral) decisions.

During the joint writing activity analyzed for this article, students co-wrote two letters with their partner-one for a Spanish-speaking friend or relative and the other for an English-speaking friend or relative (during Spanish instructional time and during English instructional time, respectively). The assignment was designed to give the students an authentic purpose and audience for their writing in both languages. In the letters, the students 
described themselves, focusing on the classmate whom the letter recipient did not know. To brainstorm content for the letter, they followed an interview guide that asked the students to recount a memorable experience and to find out something they had in common with each other. They were required to co-author a shared piece of writing, in contrast to their usual writing assignments that required independent authorship. Some of the students struggled with their shared, narrative voices, reflected in their usage of mixed firstperson and third-person perspectives. However, this did not mean that one student did all of the writing; in fact, it was common for a student to write about herself in the third person. It is unclear how much of this struggle with author voice was due to a lack of familiarity with the format of shared narrative and how much of this struggle was a true battle over writing territory. Due to the limited scope of this article, a discussion of this point will be reserved for future research. To further encourage equitable collaboration, the students were required to switch roles as the writer (i.e., interpreted as being in control of the pencil) every few sentences and were encouraged to "write out loud" so their writing partner could hear what they were writing during the composition process. Although the students' writing did not often reflect a shared narrative voice, I found that the students co-created the texts in other ways throughout the process, which will be discussed later. For example, their oral discussions while writing reflected a high degree of mutuality (Storch, 2002). After the letter writing activity in Spanish and English, students completed self-evaluation rubrics about collaboration, which guided them think about what collaboration looks like in action. After they completed the activities, I interviewed the students individually to ask about where they received or gave assistance with language.

\section{Data Analysis}

I read through field notes and transcriptions several times to seek out salient categories of talk that emerged from the data (following qualitative analysis described in Emerson et al., 1995; Erickson, 1998; Miles \& Huberman, 1994). To focus the coding of transcriptions and to capture the learners' attention to language, I identified LREs during the interactions. An LRE was identified when students explicitly reflected on their language usage, asked questions about language, or played with new language forms. I initially used LRE coding categories from previous studies (Fortune \&
Thorp, 2001; Foster \& Ohta, 2005; Mackey et al., 2000; Swain \& Lapkin, 1998); however, I found that much of the talk between the students was not captured by previously defined categories of LREs (morphosyntax, phonology, lexicon, and semantics), so I developed three additional coding categories (crosslinguistic analysis, sociopragmatics, and written conventions) to describe other salient features of student talk about language (for more detailed examples of each category, see MartinBeltrán, 2006). An LRE could be short, involving two turns of speech, or could occur over several turns of speech with tangential remarks inserted in between their questions or doubts about language usage. In the excerpts presented here, the reader will notice that students may engage in several LREs that overlap and build upon each other.

Language-related episodes involving lexicon were the most common kind of episode found in the recordings of peer interactions during the focal activity in both Spanish and English instructional time. This was consistent with classroom observations of other activities when students often solicited help from one another with quick confirmation checks or "How do you say $\mathrm{x}$ ?" During this writing activity, even apparently simple word-toword translations often led to further discussion, other linguistic problems, or reformulation of entire sentences. Lexical LREs often overlapped with other categories, such as semantics and syntactic structure of sentences, which is exemplified in the excerpts. Please note that counting LRE categories was not the focus of my study. Instead, I focused on the nature of the LREs using a sociocultural lens to analyze moments at which language competence was explicitly discussed and simultaneously constructed. The excerpts selected represent the content and kind of speech from the larger sample of LREs found throughout student interactions (across 20 students involved in the same activity).

\section{Student Participants}

I have chosen excerpts from 8 students (four dyads) who represent a range of language proficiencies and literacy levels (as seen in Table 1). Among the 20 students in the class was a varying degree of mutuality and equality; however, for the purposes of this discussion I deliberately chose examples of interaction for which students were involved in LREs, which depended on a certain level of mutuality and collaborative behavior (see Storch, 2002). Missed opportunities and challenges are discussed further in other works (Martin-Beltrán, 2007). 


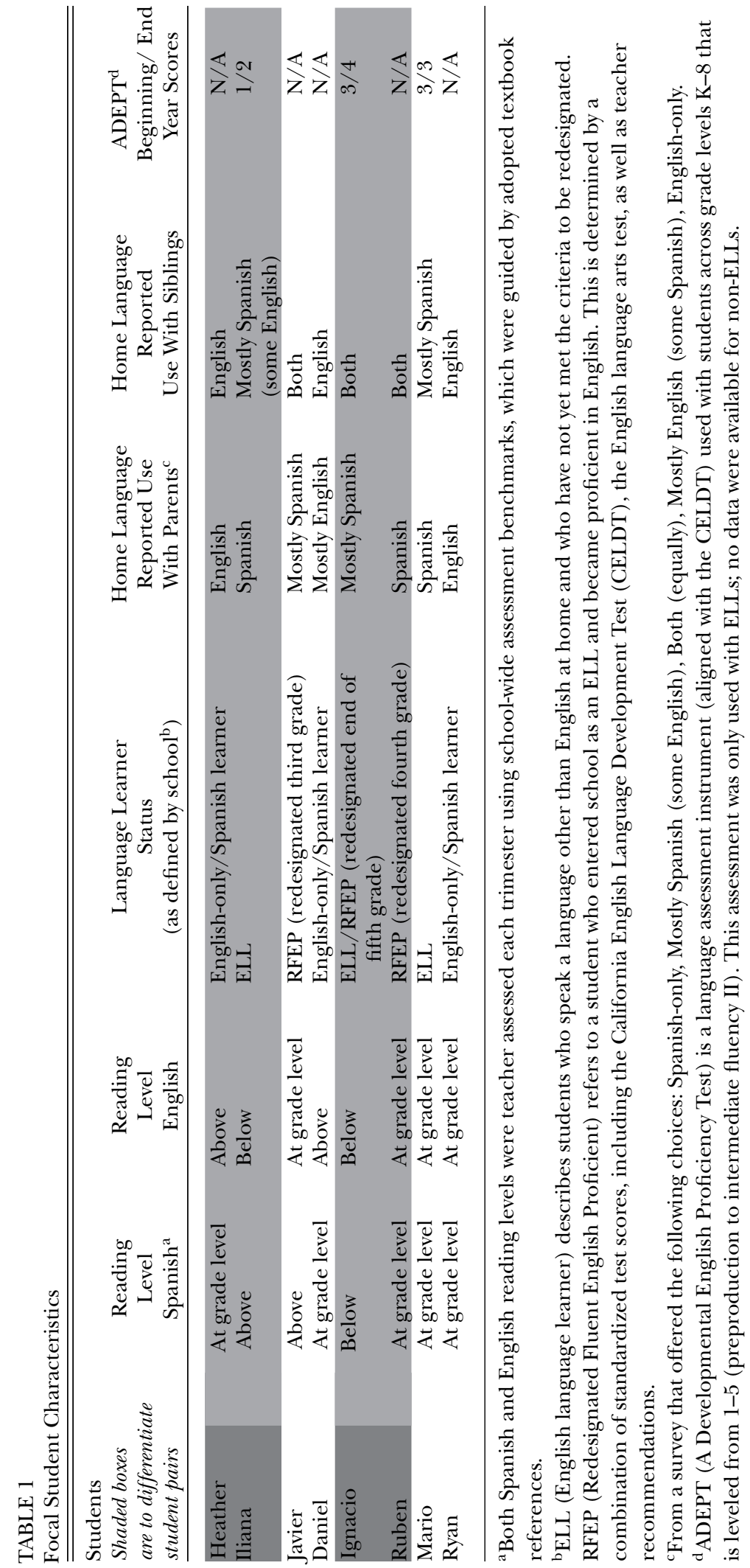


Table 1 provides a summary of basic language proficiency descriptors of all of the students highlighted in the excerpts. I offer this chart to reflect the kind of information that was available to the teacher and used to inform instructional decisions; however, it is important to recognize the limitations of such measures to capture the situated nature of language competency. Seven of the 8 students (all except Heather) highlighted in these excerpts could be considered heritage language speakers of Spanish because they have some family members who speak Spanish, although Valdés (2005) and others have explained that this label refers to a wide range of language experiences. Valdés (2005) described heritage language speakers as "L1/L2 users" who "fluctuate in their preference or perceived strengths in each language..." depending on contextual factors (p. 414). To contextualize each student's language experiences, additional background information about each participant will be discussed in each excerpt.

\section{Findings}

The findings of this study indicate that student interactions offer rich affordances for language learning when students are given the opportunity to draw on two or more languages simultaneously in dialogue with members of distinct linguistic communities as they participate in joint activities. Given time constraints on this classroom-based study, it was not possible to develop individualized assessments that would assess learning or changes in language development as a result of these interactions; instead, this analysis focused on LREs as opportunities or contexts for potential language learning. As I discuss the findings, I will draw on a sociocultural framework to qualitatively examine how learning opportunities emerged during student interactions. The following excerpts demonstrate the linguistic and metacognitive accomplishments of the students who were simultaneously expanding opportunities for language learning. I argue that using two languages as tools for mediation further expanded opportunities for learning. The students' dual language use not only deepened metalinguistic analysis but also multiplied the language learning affordances within the interactions.

Two Languages Bridge Gaps for One Student, Become Learning Opportunities for Another. The conversation samples presented in Excerpt 1 take place between Heather and Iliana, who were both academically strong students, yet they both expressed frustrations and explicit awareness of their weaknesses in their L2s. Heather was perceived as a strong English speaker and a weak Spanish speaker by her peers, although her literacy skills were considered at grade level in both languages. Heather described herself as one of the only blonde girls in school, which she recalled as a difference she felt when she entered Escuela Unida in the first grade. Heather was confident of her academic abilities, and when working in small groups, she often assumed a leadership role. As a recent arrival from Mexico, Iliana came with strong language and literacy skills in Spanish but very little prior instruction in English. Iliana arrived with her family from Michoacan the summer prior to this study to join her cousins in California. Prior to enrolling at Escuela Unida, she attended 5 years of school in Mexico, where she developed strong literacy and study skills. Although she was a new student, she demonstrated confidence and leadership when working in groups. Outside of the classroom, Iliana and Heather rarely spent time together socially.

The girls described the complexity of their bilingual competence, which included imbalanced perceived proficiencies (Martin-Beltrán, 2007) when they wrote, "We are both bilingual and speak more one language than the other." Their difference in proficiency levels suggested an "expert/novice" relationship in terms of Storch's (2002) definition of low equality and high mutuality among participants. Although Iliana seemed to take control of the writing task at times, their resolutions and revisions seemed acceptable to both participants and there was evidence of reciprocal feedback between both girls. I observed each student take on the role as novice and expert at different points throughout the interactions, especially when comparing their letter writing across Spanish and English. This school setting, which recognized both Spanish and English as important linguistic resources, offered an important opportunity for an English language learner (ELL) to be placed in a position of prestige and power in contrast to mainstream educational settings in which ELLs are often assigned low academic status (Christian \& Bloome, 2004; Yoon, 2007, 2008). Although Heather contributed her academic capital and experience as a veteran in this program, she also depended on her newcomer partner, Iliana, to co-construct the text and often take the lead in composing in Spanish.

In Excerpt 1, Heather was describing a frightening moment when she and her friend almost fell out of a tree. Iliana acted as an active listener as she transposed this experience to written form for the letter to her cousin. 


\section{EXCERPT 1}

\section{Original Utterance ${ }^{6}$}

1 Heather: Yo estaba como diez pies del . . . suelo

2 "and" una cosa que se cayó en su lado

3 y...yo estaba... "leaning?"

4 Iliana: ¿Qué?

5 Heather: Leaning?. .

6 Iliana: [look of confusion from Iliana]

$7 \quad$ Heather: Como así

"I'm leaning" en mi brazo

8 Iliana: ¿inclinada?

9 Heather:: . . . estaba inclinada en una cosita del árbol como así

10 y inmediatamente se quebró esta cosita y fue como así en el árbol y ya mero me caí!

11 H\& I: @@@

12 Heather: Estaba como así en el árbol!

13 Iliana: A ver. .

14 'Ella estaba con su amiga en un árbol cuando una' ... este... ¿una parte?

15 Heather: Un pedazo del árbol se cayó y ya mero se cayó :: al piso...@@... al suelo::

16 Iliana: ::una parte del árbol se cayó::

17 Heather::: It's so confusing!::

[she whispers under her breath, frustrated]

18 Teacher: What's so confusing?

19 Heather: How like outside it's different than inside on the floor. . "piso or suelo." Like floor and dirt. We don't say that, we say ground and ground or floor and floor :: or dirt or no uh ::

20 Iliana: Ok, que les parece?

21 'Ella estaba con su amiga en un árbol cuando una parte del árbol se quebró y estaban a punto de caerse'

\section{English Gloss (when needed)}

[actions and comments in brackets]

I was like 10 feet from ... the ground

[She lifts her arm to show height]

"and" a thing fell by her side

[pantomimes a falling branch]

and ... I was ... "leaning?"

What?

\section{Like this}

[showing movement by leaning over her chair]

"I'm leaning" on my arm

Inclined/leaning

...I was leaning on a little thing from the tree like this

[leaning over on chair]

and immediately it broke, this little thing, and it was like this on the tree and I almost fell!

[pretending to fall]

[both girls laugh]

I was like this in the tree!

[She shows herself hanging on, leaning over her chair]

Let's see... (pause 12 seconds) [She puts the pencil to her mouth as she is thinking, then she begins to write out loud]

She was with her friend in a tree when $a$...um ... a part? [with rising intonation] A piece of the tree fell and she almost fell to the floor [laugh] ... to the ground

... a part of the tree fell

[she speaks softly out loud what she writes]

Ok, how does this sound to you?

[She announces and reads what she has written]

She was with her friend in a tree when a part of the tree broke and they were just at the point of falling

Yes that's good 
During the interaction transcribed in Excerpt 1, several kinds of LREs occurred. Heather and Iliana discussed and repaired lexicon and syntax and created simultaneous opportunities for language learning in both Spanish and in English (even though this activity took place during Spanish instructional time). When Heather encountered a lexical dilemma during her story telling (line 3), she paused and then inserted the word in English (the nontarget language) in a rising intonation to signal questioning and a request for help from her partner. Using English (her dominant language) gave her a way to continue the story; yet when Iliana did not immediately translate the English word, Heather was compelled to use other strategies (such as gesture and physical demonstration) to communicate her ideas and elucidate the meaning of the unfamiliar word to Iliana. While demonstrating the action, Heather contextualized the English word in a Spanish sentence ("I'm leaning en mi brazo"), codeswitching coherently and adapting a common teacher strategy to explain a new word by using that word in a sentence. Different from teacher talk, which promoted a monolingual model in this instructional space, the students created a bilingual interactional space (Lee et al., 2008) drawing on two linguistic codes simultaneously. The teacher could have extended this crosslinguistic comparison by calling attention to the different ways that Spanish and English words express the manner in which motion events occur. ${ }^{7}$ In this instance, the teacher did not intervene but allowed the students to resolve this problem of word choice on their own, thus emphasizing the importance of peer collaboration and interdependence.

By repeating the new English word "leaning" three times and contextualizing this word within Iliana's dominant language, Heather provided comprehensible input and together they created increased language learning affordances in both Spanish and English. Iliana demonstrated her understanding of the new English word "leaning" when she offered the Spanish word inclinada, which Heather appropriated to continue her next sentence (line 9). This evidence of uptake (or use and incorporation of the new vocabulary) is considered an important step toward language development (Gass \& Selinker, 2001; Mackey, Oliver, \& Leeman, 2003; Oliver, 2000). Beyond simply receiving and using the new language (which traditional definitions of uptake suggest), I argue that Heather and Iliana are appropriating new knowledge through this dialogic interaction. Appropriation is an ongoing process that describes the ways that learners are transforming texts, learning processes, artifacts, and situations as they make them their own (see Rogoff, 1995; Wells, 1999; Wertsch, 1998). In the discussion section, I will further explain how the sociocultural concept of appropriation illuminates the transformational processes and co-construction of language knowledge during these interactions.

Although a monolingual analysis of this interaction might focus on the gap in Heather's Spanish lexicon, a bilingual, two-way analysis reveals the way this gap created additional opportunities for learning both English and Spanish. In this case, Heather's struggle with language created an unexpected, unplanned (in terms of the teacher's objectives), and often unacknowledged opportunity for Iliana to learn a wider range of English vocabulary. By using English in place of the missing Spanish word, Iliana was presented with new English lexicon within a meaningful context. Their use of two languages to understand the meaning of "leaning" also afforded additional opportunities for the students to compare (or at least become exposed to) different languages' conceptual frameworks for expressing motion events, which might be expanded in the future. A bilingual analysis of this interaction calls attention to bidirectional language learning; for example, in this moment when both students were struggling and negotiating for meaning, both students were also potentially developing their respective target languages.

Refining Understanding of Academic Language Through Interaction. As Iliana began to read aloud her written work to clarify meaning and ask for approval from her co-writer, she echoed Heather's earlier strategy to initiate an LRE_rising intonation to signal a question and a request for help-as she searched for a more specific, academic word to replace una cosita 'a little thing' (line 14). Iliana's questioning elicited other suggestions from Heather, who offered a synonym un pedazo 'a piece' (line 15). Although Iliana did not take up Heather's suggestion, she did incorporate the rest of Heather's sentence (beginning with se cayó in line 15)-demonstrating the ways they were coconstructing this text. Foster and Ohta (2005) described co-construction as "allowing learners to participate in forming utterances that they cannot complete individually, building language skills in the process" (p. 420).

At the end of this excerpt, we see further evidence of linguistic work accomplished during the collaborative interaction, when Iliana reformulated Heather's sentences by substituting lexicon (una parte for cosita or Heather's suggestion of pedazo) and repairing syntax (estaban a punto de caerse- 'they were at the point of falling'). 
Iliana also contributes her understanding or sensitivity to academic register when she transforms the colloquial, informal phrase ya mero to a more formal register, estaban a punto de caerse. The nature of the assignment required both participants to pay attention to linguistic transformations, as the oral telling took on a written form using academic language and both students shared in the composing and reading of the new text.

Two Languages Promote Metalinguistic Awareness and Private Speech Becomes Collaborative. As Heather was retelling her story (line 15), she initiated another LRE as she struggled with word choice (piso/suelo) and considered different contexts in which to use and distinguish these words across her two languages. After Heather had a moment to reflect on her sentence, which she repeated for Iliana to write, she verbalized her thinking in the form of private speech (Thorne \& Lantolf, 2007; Vygotsky, 1978) as she expressed her confusion between lexical choices ("It's so confusing!" in line 17). The teacher played a key role in this interaction when she noticed Heather's remark and she encouraged Heather's verbal problem-solving process by asking, "What's so confusing?" Heather's private speech, or selfdirected questioning to help direct one's own mental activity when confronting cognitive difficulties (DiCamilla \& Antón, 2004; Donato, 2000; Thorne \& Lantolf, 2007; Vygotsky, 1978), became socially mediated when she engaged in conversation with the teacher. This is an example of how "cognitive processes derived dialogically can be observed directly in linguistic interactions that arise among speakers as they participate in problem solving tasks" (Donato \& Lantolf, 1990, p. 85). This dialogue with the teacher provided a window into Heather's cognitive processes of assessing the appropriateness of alternative lexicon for "floor/ground" depending on the context. Although Heather's linguistic confusion was left unresolved, this metacognitive moment afforded Heather an opportunity to think metalinguistically as she verbalized the usage rules for "floor/ground" by comparing Spanish and English. Through this crosslinguistic comparison, she used language as a tool for mediation and as an object for analysis. This demonstrates further evidence for how two languages offered additional affordances to engage in metalinguistic analysis, comparing semantics and lexical choice in different contexts across languages.

Heather's switch to English, as private speech, exemplifies a case where a learner draws on her L1 in order to think metacognitively (see Anton
\& Di Camilla, 1998); however, as social speech, this switch to English also excluded Iliana from the conversation (as Iliana was often positioned as a nonmember ${ }^{8}$ of the English community and it was more difficult for her to participate in English-only conversations). While the teacher and Heather were having their conversation on the side, Iliana was busily writing the text. The teacher might have redirected this situation to draw Iliana into this questioning and crosslinguistic comparison, thus multiplying opportunities for increased metalinguistic awareness for both students in both languages.

Two Languages Inspire Crosslinguistic Word Analysis and Linguistic Creativity. In contrast to the first pair discussed, the students in Excerpt 2 were more similar in their language strengths as heritage language learners, although they also came from homes in which different languages were primarily spoken. Daniel and Javier were both recognized by their teachers as good students in both Spanish and English. The boys told me they were good friends, which is also apparent from the way they played together during recess and lunch time with a common group of friends.

Javier's parents were born in Mexico and spoke only Spanish at home, but Javier told me about an extended network of family members who were bilingual and well established in California, where he was born. On the schoolyard and during small-group classroom activities, Javier moved comfortably between Spanish and English with his peers. He was often called on to explain concepts in both English and Spanish classes and his peers recognized him as a good helper in both languages. ${ }^{9}$

Daniel reported that his parents knew Spanish, but they spoke mostly English at home with him and his two older siblings. He described his mother as Filipina and European in origin and also as a fluent Spanish speaker who majored in Spanish in college. Daniel described his father as a Mexican American who grew up in Texas in a bilingual family. Daniel spoke both Spanish and English with his friends but showed higher preference for English in social situations.

Excerpt 2 was part of a conversation between Daniel and Javier who were discussing Javier's scariest memory to share in their letter. Javier told Daniel that he did not have nightmares after his scary experience and Daniel wrote this in the letter. As Daniel wrote the word "nightmares" and read it out loud, he and Javier began to talk spontaneously about the meaning and structure of the word. 


\section{EXCERPT 2}

\{English translations in curly brackets when needed

$1 \quad$ Javier: When he looked back ... there was nobody there

Daniel: There was nobody there [Daniel talks slowly as he is writing]

Javier: He thought it was the grim reaper@@

Daniel: @@ 'He thought it...was the grim reaper.' [writing what Javier said] Did you have nightmares?

Javier: No

Daniel: 'But he didn't have nightmares' [Daniel writes, reading out loud] .... Why do they call them nightmares if they're not - night mirrors?

Teacher: That's a good question!

Javier: That's a scientist ::[inaudible overlap] ...mirror::

Daniel: ::Yeah, I've been thinking since like 5 years old ... mirrors

Teacher: Do you think they're like a mirror of what you've seen all day?

Daniel: Yeah... Once I watched a movie and ... there was this garden and this lady wanted to save the kids ... the movie was called 'The Haunting.' In the garden she saw somebody hanging from the top, the kid... and she was like [drops his jaw, slaps his hands on cheeks] @@@

Javier: @@

Daniel: And then all the other people were like ahh!... And when I went to sleep I had a nightmare. You know how flashing stuff like... scares you?

Javier: Oh flashing like... flashing through your eyes?

Daniel: Like shoom, shoom, that happened to me and I was like sweating!

Javier: Ok, My turn my turn! One time, at night it was the middle of the woods or something

Daniel: Oooooh [pretending to be scared]

Javier: I was hiding. Here's like the tree, I was hiding like that [with the pencil demonstration and the eraser behind the tree] He was floating like that... I turned back, he said boo! I ran but I couldn't run that fast because it was an escalator. Then some dead people rised up from the ground and I waked up... It was like one in the morning and I could not sleep any more! It was a bad nightmare!

Teacher: That sounds scary. So it's called nightmare in English. How do you say it in Spanish?

Daniel: Un neetmare [trying to use Spanish phonology]

Javier: No no.... Sueño mal $\{$ bad dream $\}$ or something like that... or pesa ... oh yeah, ::pesadilla:: [overlap with Daniel]

Daniel: ::Pensamiento?:: $\{$ thought

Daniel: Oh yeah, “pesos” ... Oh I know pesa like your día was pesado $\{\mathrm{Oh}$ yeah "weights” Oh I know like "to weigh" like your "day" was "hard/heavy"\}

Javier: Dia like hard day, pesado dia like pesa ... día \{Day like hard day, heavy day like nightmare\}

Daniel: Oh! ... I think I know what 'mare' means, it's like a schmare ... is like something scary that doesn't really happen, but you believe in it!

Both:@@@ they both laugh]

Both: @@@ [they both laugh] 
Excerpt 2 exhibits several key qualities that were important for creating a rich context for language learning in this interaction. First, the participants created a space to play with language and ask questions about language. To use Swain's (2006) sociocultural term, they were involved in languaging and language play (G. Cook, 2000; TocalliBeller \& Swain, 2007). This conversation between Daniel and Javier called attention to language when Daniel asked a rhetorical question about language (line 6). This practice of asking questions about language was often observed in the classrooms in which teachers and students were encouraged to be curious about words and differences between languages. In this excerpt, the teacher advanced this curiosity by asking more questions (lines 7 and 19). Javier affirmed that Daniel was acting like a "scientist," who asks good questions-a phrase often repeated by their teachers (line 8). The students were able to explore the meaning of "nightmare" further and share rich, descriptive language as they each told their stories of scary nightmares (lines 11-18). Similar to Excerpt 1, this interaction in two languages expanded the students' vocabulary and may have refined academic vocabulary. For example, instead of limiting his vocabulary to "bad dream," Javier was encouraged to use the more specific term for "nightmare" and thus exposed Daniel to more academic language in Spanish. Similar to Excerpt 1, the new lexicon (pesadilla) was embedded in a meaningful context, increasing the comprehensibility of this language for both learners.

The teacher was an important participant in this interaction as a co-constructor of the collaborative dialogue. She encouraged their questions about language (line 7) and asked her own questions, which inspired further dialogue (line 10). She became involved in the language play and encouraged the students to expand and extend their word analysis across language boundaries. Without the teacher's question comparing English and Spanish (see line 19), it is unlikely these students would have reached this level of crosslinguistic word analysis on their own. The teacher's scaffolding and inquiry about the comparison of the two languages opened further opportunities for metalinguistic awareness and co-construction of language knowledge.

Building Off Each Other's Expertise. The boys demonstrated a high level of collaborative coconstruction evidenced in their back-and-forth storytelling and their animated dialogue. Their collaborative dialogue about writing illustrated many instances of co-constructions as defined by Foster and Ohta (2005). For example, Daniel and Javier echoed and built on each other's previous statements as new ideas emerged, developed, and changed. Their interaction during this activity was very friendly and would be described as collaborative, in terms of Storch's (2002) definitions of high equality and high mutuality. Both Javier and Daniel took directions from each other, they contributed jointly to the composition, and they engaged with each other's ideas, showing high levels of cohesion (repeating utterances and extending on each other's utterances).

This excerpt also highlighted the importance of the social activity of learning during interactions. The playful nature of the dialogue (evidenced by laughter, overlapping speech, ludic talk, and oneup-manship) seemed to encourage languaging. A sense of solidarity framed their interaction, as evidenced in the final lines of the transcript when they recognized they shared common experiences and perspectives ("we both have scary dreams," line 29).

Another feature of this dialogue that a sociocultural lens helps to highlight is the way they used language explicitly as a tool for mediation and an object for analysis. This example expands previous empirical evidence that has demonstrated the use of the L1 as a tool for mediation to analyze the L2 (Anton \& DiCamilla, 1998). In this case, both languages became "objects for analysis" and "tools for mediation" during the interaction. This interaction demonstrates the complexity of a two-way learning process that constantly moves back and forth between languages. There were several instances when the use of two languages offered greater affordances for the students to analyze language. For example, in response to the teacher's question about how to say "nightmare" in English, Daniel demonstrated his metalinguistic understanding as he tried to extend cognate rules (phonological transfer patterns) and tried to apply these rules (albeit incorrectly) to a new context to create new knowledge (see line 20). His partner, Javier, drew on his own linguistic funds of knowledge (Moll, Amanti, Neff, \& González, 1992) as a dominant Spanish speaker and contributed to this construction of knowledge by providing authentic Spanish alternatives. Javier demonstrated his expertise by correcting Daniel and finally producing the precise word in lines 21-25.

After Javier shares the word pesadilla, we observe an interesting case of uptake (that went beyond traditional definitions of uptake in terms 
of using new linguistic input) when the boys collaboratively engaged in the transformation of the word. Instead of passively receiving this word or simply incorporating this word into their next utterance, they deconstructed the new word and analyzed each part of the word to further understand its meaning. The back-and-forth language play using two languages provided an important scaffolding opportunity for David, for whom $p e^{-}$ sadilla was an unfamiliar word prior to this transformative dialogue. In lines 20-26, the boys used both Spanish and English as tools of mediation as they transformed the word parts pesado 'heavy' and dia 'day' into the phrase "hard day." Daniel verbalized his analysis and Javier agreed and extended this analysis, which seemed to bring about further revelation for how word meanings and origins may fit together. Finally, Daniel returned to his original question about the English word "nightmare" and he hypothesized a new meaning for the word part "mare" (or "schmare") as "something scary that doesn't really happen, but you believe in it" (line 26). Javier and Daniel invented their own etymology of this word that was not exactly accurate, but, more importantly, they went through a transformative analysis process that inspired further thinking about language and appropriation of new co-constructed knowledge.

This collaborative dialogue offered a unique space for linguistic creativity. In Javier and Daniel's interaction, we observed how the students used "texts as thinking devices and responded to them in such a way that new meanings were generated" (Wertsch, 1998, p. 115). For example, when they played with the words "nightmare" and pesadilla, not only did they generate new meanings for word roots, but they also generated a new definition for their invented word "schmare." The excerpt demonstrated the ways that students drew on their resources in both Spanish and English to solve linguistic problems. Their dialogue could be described as throwing a metaphorical boomerang across languages, when they began their metalinguistic analysis in language $\mathrm{A}$, transferred this knowledge to analyze language $\mathrm{B}$, then returned to language A with new insight and possibly a deeper level of analysis that had transformed their learning processes.

Two Languages in Dialogue Allow for Analysis of Multiple Meanings and Social Relationships. Excerpt 3 occurred between Ignacio and Ruben, who were of similar language backgrounds. Both Ignacio and Ruben spoke Spanish with their parents (who had emigrated from Mexico during the past decade), and they used both English and Spanish with their siblings. In an interview, Ruben's mother had told me how her son often acted as a translator for the family. She encouraged her son to use well-formed Spanish, avoiding palabras acomodadas, or borrowed English words incorporated into young people's Spanish vocabulary. Ruben brought this language awareness to school and also proved to be an agile translator in the classroom. Ruben was classified as a "redesignated fluent English proficient" student. He was reading at grade level in both Spanish and English. Ignacio and Ruben both used English and Spanish fluently during social activities.

In fifth grade, Ignacio had not yet tested as officially English proficient, but his teachers suggested that his low English Language Development scores were an indicator of Ignacio's low literacy skills. He was reading below grade level in both Spanish and English. Ignacio's mother told me she was proud of her son's proficiency in English, but she was worried about her son's progress in school because of behavior issues. In the subsequent excerpt, Ignacio displayed his class-clownlike behavior when he chose to discuss a topic that he knew may be considered inappropriate but would appeal to a fifth-grade boy's sense of humor.

Ignacio and Ruben's interaction was collaborative, in terms of Storch's (2002) definitions of high equality and high mutuality. Both Ignacio and Ruben contributed jointly to the composition, they engaged with each other's ideas, and they extended each other's utterances. Their playful, animated dialogue also highlighted the highly social nature of their interaction where laughter, overlapping speech, and ludic talk seemed to create a context for languaging. Excerpt 3 comes from a conversation when Ignacio and Ruben were writing about Ruben's funniest moment in a letter to Ignacio's grandfather.

As Ignacio was reading out loud what he had written to Ruben about his funniest moment, they engaged in an LRE about word appropriateness. In line 2, Ruben questioned Ignacio's use of the word "gas," which he had chosen as a more polite way to say "fart." Ruben explained that there might be confusion because the word "gas" has multiple meanings. Ruben gave evidence for another meaning of the word "gas" by placing it in 
EXCERPT 3

\section{Original Utterance}

1 Ignacio: 'La cosa mas chistosa que pasó fue cuando el hermano de mi amigo se echó un gas@en la cara de otro niño’@@

$2 \quad$ Ruben: ¿Un gas?? @@@

$3 \quad$ Ignacio: @@@ He did like this [fart noise]

4 Ruben: It is gas @@ but he's gonna think it's gas of CAR! Does he know the other word ... for gas?

5IIgnacio: @@@ Yes, pero, que digo ... [whispers] pedo?

6 Ruben:@@sabe esta palabra ...tu abuelo?

7 Ignacio: Claro@@ pero... ipero es grosero!

8 Ruben: ¡Eres un niño grosero!

9 Both: @@@

10

Ignacio: My grandpa knows @@ I make funny noises@@

\section{English Gloss (when needed)}

'The funniest thing that happened was when my brother's friend passed gas @@ in another boy's face'@@

[whispering and giggling, he reads what he has written]

A gas??@@@

Yes, but, what should I say... [whispers] fart?

Does your grandpa know this word?

Of course@@but...but it's rude!

You're a rude boy!

[shared laughter] another context in English (line 4, "gas of car"). Then Ruben asked his partner about the letter recipient's familiarity with the "other" word (line 4).

Ignacio demonstrated his understanding that "knowing" a word goes beyond knowing its meaning, but also knowing when it might be considered rude or inappropriate (line 7). He explained that the dilemma was not simply whether his grandfather knew the word but whether the word would be the right word to use in this context because this word would be categorized as grosero 'rude.' Ruben plays on Ignacio's descriptive word grosero to come back to describe Ignacio as a rude user of the word (" $E$ Eres un niño grosero!” in line 8). By whispering and giggling, both boys demonstrated their knowledge that pedo 'fart' was taboo in their school setting and would be considered impolite with some older adults, like the teacher or Ignacio's grandfather. They discussed the appropriateness and perception of their audience. In the end (line 10), Ignacio pointed out that his grandfather was familiar with him and may allow for a more intimate or informal kind of language that is different from school settings. As a result of this LRE, they erased the word "gas" and changed it to pedo. This change also reflected their willingness to co-construct the text.
Like the other excerpts, this was another case of dialogic interaction when the students drew on their two languages as resources and tools to analyze language as an abstract object. These students did not stick strictly to the language of instruction (Spanish) but instead used both English and Spanish in their interaction. This is also an interesting case because-contrary to earlier studies that have shown how the L1 is often used as a tool to analyze the L2-these students used what most would call their "L2" to analyze and talk metacognitively about their "L1." This is an example where L1 and L2 are not appropriate labels for these students who have developed bilingual proficiencies in a highly bilingual context.

This interaction was one of the many examples where students drew on their pragmatic and cultural knowledge learned in their multiple communities of practice. What is unique about this excerpt and the next is the participants' explicit attention to the cultural meaning of language that went beyond their knowledge of linguistic systems or la langue (Agar, 1994; Saussure, 1959). The students in this dual immersion context were able to accomplish sophisticated forms of crosslinguistic comparison not solely because two languages were the topics of academic study. In addition to their academic and linguistic 
knowledge, students offered deeper understandings of social language, which reflected their participation in very different communities of practice beyond the boundaries of the classroom (Lave \& Wenger, 1991). These LREs went beyond what one might expect in a one-way context or an L2 classroom that is distanced from authentic target language community members.

Interpreting Word Choice: Letter Greetings to Mark Social Relationships. The dialogue in Excerpt 4 demonstrates these students' awareness that word choice signifies relationships between people (in this case, between the letter recipients and the students writing the letters). The students involved in this dialogue shared similar home languages and immigration status - both students had been born in the United States and spoke Spanish with their parents, who had emigrated from Mexico 10-15 years ago. Lorenzo told me that his Spanish was much better than his English and he preferred to use Spanish with his older siblings and friends. Johnny told me his English was better than his Spanish, but he used both languages equally with family and friends. The nature of this interaction is more difficult to define using Storch's (2002) four quadrants, in part because the teacher plays an intervening role. This interactive relationship showed qualities of low to moderate equality and mutuality, falling between expert/novice and dominant/passive. Lorenzo seemed to assume authority over the task, and Johnny was ready to simply accept Lorenzo's revision without discussion (see line 4). However, Lorenzo showed higher mutuality when the teacher intervened and asked them to think about why they would choose a particular word. Lorenzo paused (in line 3) to ask Johnny for his opinion, thus encouraging his

\section{EXCERPT 4}

\section{Original Utterance}

1 Lorenzo: 'Querido Miguel'

Estimado mejor ¿no?

2 Teacher: Depende de...iqué crees?

3 Lorenzo: ¿Lo quieres mucho, mucho, mucho?...

...o 'estimado'

4 Johnny: Estimado

5 Teacher: ¿Por qué? Tu crees que estimado es más como-

6 Johnny: I don't know.

7 Lorenzo: Porque querido suena como más ... Como...

8 Teacher: ¿Con quien usas querido?

9 Lorenzo: Como querido.... como con ::tu mama::

10 Johnny: :: Como con alguien que quieres? ¿O amo? ::

11 Teacher: $::$ ¿Con tu mamá?::

12 Johnny: I like my cousin!

13 Teacher: Entonces ¿Martín es un primo querido para ti?

\section{English Gloss (when needed)}

[actions and comments in brackets]

Dear Miguel

[Reading the written letter aloud]

Better to say esteemed, no?

It depends... what do you think?

Do you really, really, really love him?... [asking Johnny]

...Or [write] 'esteemed'

Esteemed

Why do you think esteemed is more like...

Because dear sounds more like... like

With whom do you use 'dear'?

Like dear... like with your mom

Like with someone you like?

... or love?

With your mother?

So, Martin is a dear [close] cousin for you?

Better. . $x x x$

[decides to leave 'querido' on paper and goes on to reading the next sentence] 
partner's participation. However, there were also instances when Lorenzo ignored Johnny and instead addressed the teacher. In Excerpt 4, these students were rereading and revising their letter to Johnny's cousin when they engaged in an LRE to discuss the appropriateness of a letter salutation.

As Lorenzo read what Johnny had written to begin the letter, he suggested that they write estimado rather than querido as a salutation because querido ${ }^{10}$ may express feelings of tenderness that are not appropriate for a formal letter to his cousin. To further evaluate the word choice, Lorenzo asked Johnny how close he really felt to his cousin (line 3), suggesting that querido in a letter would be the exception and estimado would be more appropriate unless he "really liked" his cousin. At first, Johnny quickly agreed that they should use estimado. When the teacher intervened to ask why they wanted to use estimado, Lorenzo explained that it sounded strange because querido is a word to use with one's mother (lines 7 and 9). Johnny extended Lorenzo's definition for querido to include any person one cares about (line 10). On further consideration, Johnny draws on English to demand attention (line 12: "I like my cousin!"), to defend his position, and possibly to draw attention to a distinction between the feelings of love and like that he was having trouble explaining in Spanish. With his counterevidence and with the teacher's support, Johnny convinced Lorenzo that his word choice of querido was appropriate for this context.

Although the text was not modified in this case, their disagreement over word choice presented an opportunity to analyze the significance of words and to consider the implications of their language for social relationships with their potential readers. The teacher acted as a key mediator in this situation to redirect their thinking about register. Without the teacher's intervention in this interaction, this kind of metalinguistic conversation may not have been possible between the boys. Although they brought different understanding of register (and range of word choice) to the situation; together they created an opportunity to learn about what register may signal and what kind of language is appropriate in certain settings and relationships. Thinking about why they selected certain words allowed them to draw on and demonstrate their cultural knowledge of language use. The discussions about word choice and appropriateness illustrate the inextricability of language and the cultural beings who use the language. This dialogue demonstrates the situated nature of languaculture knowledge (Agar, 1994; Lantolf, 2006) that shifts and only becomes meaningful in social relationship with others. These examples suggest researchers need to give more attention to languaculture, which recognizes the unity of language and cultural practices. Due to space limitations of this article, the concept of languaculture and the importance of social discourse will not be elaborated here but should be explored in future research (see Martin-Beltrán, 2006).

In Excerpts 3 and 4 the students extended their conversations to include relationships beyond the immediate class context to choose their language appropriately. Student discussions about sociopragmatics embodied a complex form of metalinguistic talk, as the interlocutors were compelled to consider several layers of linguistic and social understanding to make choices or evaluations for what sounds good. I observed many such examples during the school day when students engaged in discussion about word appropriateness, register, or words that were considered taboo in their community (for more examples, see Martin-Beltrán, 2006). Even a brief discussion about the gravity of a "bad word" involved nuances and social signals understood implicitly by participation in a community with shared norms. Such knowledge of social discourse or appropriateness requires interaction with other members of a speech community in more intimate domains, not available in traditional classrooms. This sharing of sociolinguistic competence and metalinguistic analysis was made possible because students were able to draw on their prior experiences in which they used multiple languages for authentic, social communication in their communities outside of school. This dual immersion school context brought together members of distinct ethnolinguistic communities who were given the opportunity to contribute their unique understanding of social discourse, thereby enriching opportunities for bilingual learning at school.

\section{DISCUSSION}

The findings from this study shed light on the multiple (and sometimes unexpected) sites for metalinguistic analysis and potential language learning as students interact in dual immersion contexts. This study considered continuous, simultaneous, and reciprocal affordances for language learning during interactions between bilingual students who used two languages to go 
back and forth symbiotically as mediational tools and objects of analysis. Findings corroborate with previous studies in which peer interaction scaffolds language development (Mackey, 2007; Swain et al., 2002) and also reveal the importance of teacher intervention in these interactions. As an expert (or a more able member of society as described by Vygotsky, 1978), the teacher brings more advanced metalinguistic knowledge to the interaction, and she is attuned to the learners' needs in ways that may make the interaction more fruitful for all participants.

The excerpts exemplified the kinds of linguistic-knowledge-building dialogues that are possible in dual immersion programs both with and without teacher intervention. Whereas Excerpts 1 and 3 showed students engaging in LREs without teacher intervention, the teacher played a more pivotal role triggering and guiding the metalinguistic analysis in Excerpts 2 and 4. In Excerpt 2, the teacher was an important participant as she advanced David and Javier's curiosity about words, and she encouraged the students to expand and extend their word analysis across language boundaries. The teacher's inquiry about the comparison of the two languages opened further opportunities for metalinguistic awareness and co-construction of language knowledge. In Excerpt 4, the teacher acted as a key mediator to encourage Lorenzo and Johnny's thinking about word choice and register rather than allowing one student to dominate the decision making without deliberation. The teacher also became a participant in Excerpt 1 when she noticed Heather's confusion and she encouraged Heather's verbal problem-solving process by asking, "What's so confusing?" The excerpts also revealed examples of missed opportunities when teachers could have intervened to deepen language analysis or ensure that all students were equitably participating in the interaction (e.g., the teacher missed the opportunity to include Iliana in Heather's crosslinguistic comparison of piso/suelo). An important question for future research would be to look more closely at the implications of teacher intervention in these dialogues. More research is needed to examine how often students have these kinds of LREs when the teacher does and does not intervene to ensure collaborative work is constructive.

Common across all of the examples was the use of two languages, which opened up new possibilities for analyzing language. The students drew on a range of bilingual resources to understand a new concept, which created greater access to unfamiliar language. Using two or more lan- guages created opportunities for multiple participants to be learning multiple languages in relevant moment-to-moment interactions, which have been neglected in previous research. For example, when Heather inserted an English word into a Spanish phrase, this was simultaneously a bid for assistance and an opportunity for dual-language exchange. In other words, both participants were negotiating and appropriating new meaning in two languages. Thus, whereas the teacher's objective was not to teach English to Iliana in that particular instructional context, the students created an opportunity where Iliana would continue learning English. Different from traditional, monolingual teacher talk, these interactions were concrete examples of bilingual interactional spaces (Lee et al., 2008) where speakers used two languages to build off of each other.

By reaching outside of the "language of instruction" into their other languages as resources, the students were able to bring back new insight into the language of instruction, thus demonstrating more profound metalinguistic awareness (i.e., Daniel and Javier's analysis of "nightmare"). Contrary to earlier studies that have shown how the L1 is often used as a tool to analyze the L2, this study found that students also used what most would call their L2 to analyze and talk metacognitively about their L1. The case of these heritage language learners also demonstrated that L1 and L2 are not appropriate labels for learners who have developed bilingual proficiencies in a highly bilingual context.

Using a sociocultural lens revealed ways that young students and their teachers used two languages concurrently as tools for mediation and analysis during their joint activities. These splices of interactions in the excerpts demonstrate the dialogic, back-and-forth processes of appropriation (Rogoff, 1995). Rogoff (1995) and Wells (1999) described appropriation as a participatory process that involves the transformation of the learners' thought processes, the transformation of the artifact (in this case, the text, as it is assimilated and reconstructed by the learners), and the transformation of the sociocultural context or situation, which brings about change in the social practice. This study found that the ways that the students perceived the problem and participated in problem-solving processes were transformed throughout the collaborative dialogues. The initial problem-solving process often began as an individual telling of one's story and evolved into a joint telling as they negotiated meaning and word choice. Learners invited their partners into the problem-solving process by signaling for help or 
asking questions. The problem of "telling a story" was further transformed into a joint problem of "choosing the appropriate words" and "expressing ideas clearly and fluently." In several excerpts, the problem-solving process was taken in a new direction as learners drew on their two languages to compare metalinguistic qualities and appropriate usage.

The students were involved in collaborative dialogue, which Swain (2000) described as "social and cognitive activity... linguistic problemsolving through social interaction" (p. 111) and is therefore an occasion for language learning. Findings from my study corroborate Swain's claim that it was not only the input or the output alone in collaborative dialogue that may promote language development but "the joint construction of knowledge resulting from questions and replies" (2000, p. 112). These students' questions were not simply answered but involved complex, multilayered language analysis as they drew on their multiple languaculture resources available in this bilingual context. In Javier and Daniel's interaction, we observed how the students used "texts as thinking devices and responded to them in such a way that new meanings were generated" (Wertsch, 1998, p. 115). The students in all of the excerpts engaged in talk about language and questioned their own language use across a wide range of linguistic and social categories.

The transformation of cultural artifacts (in this case, the written and spoken text) could be observed most directly in the way that the students' utterances were reconstructed by both participants as they composed their final draft of the letters and as they drew on their prior knowledge to construct the artifact in the moment. Through the process of questioning, writing, reading aloud, asking for opinions, and questioning again, the language of the text was transformed. Their verbalizations and writing became an object of analysis or "available for scrutiny" (Swain, 2000, p. 104). The students could observe the transformation of the text as they wrote and rewrote their spoken stories, discussing linguistic form and bringing in implicit knowledge about social norms and community practices.

The situation was transformed from an academic assignment into a personal, social interaction, evidenced by the children's shared laughter, their playful banter, and their questions about relationships with the letter recipients. For example, as Heather told her story with animated pantomime and gesture, her participation in the interaction went beyond the purpose of getting this narrative on the paper and became more about involving her partner Iliana in the excitement of the moment. In the interactions between Ruben and Ignacio and between Lorenzo and Johnny, they transformed the sociocultural context by extending their conversations to include relationships beyond the immediate pair (i.e.. Ignacio's grandfather and Johnny's cousin). Their interactions demonstrated that language is more than linguistic form but also a way of mediating oneself and relationships. One can only speculate how these opportunities for extended personal conversation between these students may have changed their future interactions across languages and participation in new communities of practice.

An important part of recognizing two languages as resources in a dual immersion setting is also recognizing peers as co-constructors of knowledge. Collaborative relationships in this school setting were supported both in moment-tomoment interactions and in the larger institutional structures of the school (Gebhard, 1999), where different voices and different languages were valued as important resources.

Students positioned themselves as both experts and novices throughout the interactions as they actively requested help from their partners and offered advice. This study found that co-writing activities offered several opportunities for coconstruction (as defined by Foster \& Ohta, 2005), which recognized the value of different speakers' contributions to the text and created affordances for each participant to engage their unique language expertise. For example, the LRE that began with Daniel's English expertise to analyze the word "nightmare" developed further when Javier contributed his Spanish expertise with the word pesadilla, and this expertise was shared as both of them played with the two languages interchangeably to generate new meaning (Wertsch, 1998).

The students' recognition of shared expertise and understanding of "partner as resource" was also confirmed during the postactivity interviews. In the interviews, all of the students highlighted in these excerpts were able to refer back to specific examples in the text of the letter to point out when they gave and received help thinking about language. In their self-evaluations, the students recognized collaboration and shared decision making with their partner, which suggested high mutuality and equality (as described by Storch, 2002). It is important to note that the relationships between students were built over time within a classroom culture that supports collaboration. The excerpts highlighted in this article were 
limited in that they could not capture the full picture of these relationships and the ways they were fostered within the school context over time. For further discussion of the conditions and contexts that afford and constrain language exchange, see Martin-Beltrán (2006).

\section{IMPLICATIONS FOR RESEARCH AND PRACTICE}

This study fills a gap in educational research by closely examining opportunities for bilingual language exchange during student interactions in dual immersion programs. The interactions analyzed illustrate the unique opportunities for linguistic problem solving in a dual immersion context where two languages are framed (and utilized daily) as academic and social resources. Findings from this study provide a window into the complexity of collaborative interactions and offer educators a new lens to think about the ways in which students develop language simultaneously. Educators in diverse classrooms (bilingual, heritage language, English as a second language, and mainstream) can learn from dual immersion programs that explicitly recognize the diverse linguistic resources students bring to the classroom from their distinct communities of practice (Lave \& Wenger, 1991). Findings from this study suggest that teachers may promote language development by actively creating supportive spaces where students can play with language, co-construct language expertise, and recognize each other as resources. In this study, the teacher and researcher used extensive guides for collaboration, including modeling and self-evaluation rubrics that placed great importance on collaboration within the activities. The teacher plays a key role in interactional spaces to call attention to opportunities for learning, to extend student thinking about language and to intervene or step back in order to encourage collaborative interactions among the students. As teachers plan instruction they need to consider ways to provide guidance for co-construction of text by explicitly valuing multiple voices and modeling ways that participants can draw on their different strengths to learn together. More research is needed to understand how teachers might optimize the opportunities for language learning that could occur in interactions.

The classroom teacher alone cannot provide the wide range of language and social experiences that are representative of bilingual communities of practice. The examples of student dialogue involving discussion about social discourse demonstrate why it is so important that students have meaningful interactions with other stu- dents who are members of distinct target language speech communities beyond the school. The students enrich this learning context as they embody, construct, reflect, and re-create the social communities from which language emerges.

The findings from this study showed how learners created further opportunities for language learning as they broke language norms (violating the language of instruction) to solve a communicative problem. The students created their own bilingual norms, which were more representative of the multilingual communities outside of the classroom (Levine, 2003). In contrast to earlier studies that found dual immersion programs may promote "parallel monolingualism" (Fitts, 2006), this study sheds light on what learners are able to accomplish when given opportunities to participate in and co-construct bilingual interactional spaces (Lee et al., 2008). I argue that language learning affordances could be increased in such settings by allowing interplay between languages, by expanding language boundaries across instructional domains, and by creating multiple opportunities for language learners to hear their target languages embedded in their home languages. It is also important to give more attention to the learning opportunities that arise when students struggle with language. What may be one student's weakness could become an opportunity to build strength in both languages simultaneously.

In a setting where two languages were available all of the time, this study demonstrated that the ongoing processes of acquisition in two languages can also occur simultaneously. Whereas bilingual programs aim to develop bilingual competence, teachers within classrooms separated by language tend to focus on students' language development in only one language. Many educators seem to overlook that their students could be simultaneously accomplishing their goals developing two languages within student interactions in their class.

In response to those who may critique bilingual programs for not providing enough instruction or linguistic input in the majority language (English), this study provides evidence that English learners have increased access to meaningful language in ways that are not available in monolingual English settings. By participating in activities that require meaningful interactions between learners with different language strengths, students create learning opportunities based on their own authentic, communicative needs.

This study seeks to encourage future dialogue across the fields of SLA and bilingualism. This 
study opens up new possibilities and contexts for the study of SLA and the teaching of L2 learners by shedding light on moments of reciprocal language learning. Unlike earlier studies that have focused on LREs in one-way immersion or foreign language classrooms (Anton \& DiCamillla, 1998; Foster \& Ohta, 2005; Swain \& Lapkin, 1998; Swain et al., 2002), this research took place in a bilingual setting in which two languages were utilized simultaneously as tools for mediation and objects of analysis. The students' dialogue also illustrated the complexity of bilingualism where languages are not easily separated into L1 or L2 (Bailey, 2000; Block, 2003; Heller, 1999; Zentella, 1997). By demonstrating some (even limited) expertise in each other's languages, the students were able to create linguistic bridges, draw on multiple resources to meaningfully communicate, and create new opportunities for language learning. This intermingling of languages presents another challenge to SLA researchers who have often assumed the L2 as a discrete unit of analysis. In this unique context, students were found to engage in crosslinguistic comparisons and to combine strategies from two languages to generate a creative approach to problem solving. This unique use of two languages as tools for mediation raises further questions for research in the field of L2 learning and urges future research to more closely consider simultaneous and reciprocal affordances for language learning during interactions.

The collaborative dialogue described in this article does not happen automatically in dual immersion programs, but it is built up over time within a supportive classroom culture (see MartinBeltrán, 2006, for further discussion of classroom culture and school ecology). While I do not claim that there was language learning happening every time these students were brought together to speak with one another, I do argue that by supporting these encounters, teachers were creating the possibility that these students would come together again and continue their pursuit for learning and social understanding. These students and teachers were actively building the environment in which this kind of social and language exchange can continue to grow and transform the world around them.

\section{ACKNOWLEDGMENTS}

I am grateful to the Spencer Foundation for funding the research on which this article is based. I wish to express my gratitude to the teachers and students who welcomed me into their multilingual worlds. I also wish to thank Guadalupe Valdés, Ray McDermott, Francisco Ramirez, Phil Hubbard, and Stanford LEEP colleagues for their encouragement and support throughout my research. Finally, I would like to thank the journal editors and the reviewers for their helpful comments. This work does not necessarily represent the views of those mentioned here; I alone am responsible for any shortcomings.

\section{NOTES}

${ }^{1}$ In the United States, language-minority students are also known as English language learners previously labeled Limited English Proficient. Majority-language students refer to those who speak English at home. The definition of "language-minority student" and "native speaker" is a point of contention and ambiguity in both educational research literature and SLA studies. I use these terms here to make societal language and power relations explicit. In my research, I question these categories and I seek definitions relevant to local context. I use the term "dual immersion," although it should be noted that programs are also known as "Two-Way Immersion" or "Dual Language" (Howard, Sugarman, Christian, Lindholm-Leary, \& Rogers, 2007). I refer to a program that maintains the goals of bilingualism/biliteracy, academic achievement in two languages, and crosscultural understanding between language-minority and language-majority students.

${ }^{2}$ Although SLA research often uses categories of "native speaker" and "nonnative speaker," these terms are problematic in several ways. These categories are based on a monolingual bias, which does not adequately take into account bilingual communities in which people may be "native speakers" of more than one language or a variety of dialects. I will use this term when referring to literature that refers to "native speakers," but in my own research I seek descriptors that more accurately describe language experience.

${ }^{3}$ Valdés (2005) uses the term L1/L2 user, building on V. Cook's (2002) work, to describe the complexity of heritage students' language experiences. I use this term to describe the variety of language backgrounds of the students in dual immersion programs.

${ }^{4} \mathrm{~L} 1$ refers to first language and L2 refers to second language; however, this may perpetuate the misconception that languages are always learned separately and sequentially rather than simultaneously.

${ }^{5}$ All identifying information and names have been replaced with pseudonyms to ensure confidentiality of all participants.

${ }^{6}$ See the Appendix for transcription conventions.

${ }^{7}$ In this example, Heather demonstrated her sensitivity for manner by choosing a more fine-grained motion verb, "to lean." It is interesting that she applied gesture (showing with her body) to express manner similar to findings by Negueruela, Lantolf, Jordan, and Gelabert 
(2004), who found that Spanish L1 speakers preferred to encode manner through gesture. This presents an interesting question for further research to examine whether this exposure to two "conceptual frameworks for talking and thinking about motion events" (Lantolf, 2006, p. 86) impacts bilingual students' choice of words and gestures to encode manner.

${ }^{8}$ See Martin-Beltrán (2006) for more discussion of the discursive construction of perceived proficiencies and their power of to afford or constrain participation in language learning.

${ }^{9}$ This was reported on a survey given to students about "good helpers" in Spanish and/or English.

${ }^{10}$ The literal English translation for estimado is "esteemed" or "respected," but this is a common salutation to begin a formal letter in Spanish and is equivalent to the English "dear" in this context. Querido is used in more personal and informal letters.

\section{REFERENCES}

Agar, M. (1994). Language shock: Understanding the culture of conversation. New York: Quill Press.

Alanis, I. (2000). A Texas two-way bilingual program: Its effects on linguistic and academic achievement. Bilingual Research Journal, 24, 225-248.

Angelova, M., Gunawardena, D., \& Volk, D. (2006). Peer teaching and learning: Co-constructing language in a dual language first grade. Language and Education, 20, 173-190.

Anton, M., \& DiCamilla, F. (1998). Socio-cognitive functions of L1 collaborative interaction in the L2 classroom. Canadian Modern Language Review, 54, 314342.

Bailey, B. (2000). Language and negotiation of ethnic/racial identity among Dominican Americans. Language in Society, 29, 555-582.

Block, D. (2003). The social turn in second language acquisition. Washington, DC: Georgetown University Press.

Brooks, F. B., \& Donato, R. (1994). Vygotskyan approaches to understanding foreign language learner discourse during communicative tasks. Hispania, 77, 262-274.

Canagarajah, S. (2007). Lingua franca English, multilingual communities, and language acquisition. Modern Language Journal, 91, 923-939.

Centeno-Cortés, B., \& Jiménez, A. (2004). Problem solving tasks in a foreign language: The importance of the L1 in private verbal thinking. International Journal of Applied Linguistics, 14, 7-35.

Christian, D., Howard, E. R., \& Loeb, M. I. (2000). Bilingualism for all: Two-way immersion education in the United States. Theory into Practice, 39, 258266.

Cohen, E. G. (1994). Restructuring the classroom: Conditions for productive small groups. Review of $E d$ ucational Research, 64, 1-35.
Cook, G. (2000). Language play. Oxford: Oxford University Press.

Cook, V. (1999). Going beyond the native speaker language teaching. TESOL Quarterly, 33, 185-209.

Cook, V. (2001). Using the first language in the classroom. Canadian Modern Language Review, 57, 402-423.

Cook, V. (2002). Background of the L2 user. In V. Cook (Ed.), Portraits of the L2 user (pp. 1-28). Clevedon, UK: Multilingual Matters.

Creswell, J. W. (2007). Qualitative inquiry and research design: Choosing among five approaches. Thousand Oaks, CA: Sage.

de Jong, E. J. (2002). Effective bilingual education: From theory to academic achievement in a two-way bilingual program. Bilingual Research Journal, 26, 77108.

DiCamilla, F. J., \& Anton, M. (2004). Private speech: A study of language for thought in the collaborative interaction of language learners. International Journal of Applied Linguistics, 14, 36-69.

Donato, R. (2000). Sociocultural contributions to understanding the foreign and second language classroom. In J. Lantolf (Ed.), Sociocultural theory and second language learning (pp. 27-50). Oxford: Oxford University Press.

Donato, R., \& Lantolf, J. P. (1990). The dialogic origins of L2 monitoring. Pragmatics and Language Learning, 1, 83-97.

Ellis, R. (2005). Instructed Second Language Acquisition: A Literature Review. New Zealand Ministry of Education, Research Division.

Emerson, R. M., Fretz, R. I., \& Shaw, L. L. (1995). Writing ethnographic fieldnotes. Chicago: University of Chicago Press.

Erickson, F. (1998). Qualitative research methods for science education. In B. J. Fraser \& K. G. Tobin (Eds.), International handbook of science education (pp. 1155-1173). Dordrecht, The Netherlands: Kluwer.

Fitts, S. (2006). Reconstructing the status quo: Linguistic interaction in a dual-language school. Bilingual Research Journal, 30, 337-365.

Fortune, A., \& Thorp, D. (2001). Knotted and entangled: New light on the identification, classification, and value of language related episodes in collaborative output tasks. Language Awareness, 10, 143160.

Foster, P., \& Ohta, A. S. (2005) Negotiation for meaning and peer assistance in second language classrooms. Applied Linguistics, 26, 402-430.

Freeman, R. (1998). Bilingual education and social change. Clevedon, UK: Multilingual Matters.

Gass, S. (1997). Input, interaction, and the second language learner, Mahwah, NJ: Erlbaum.

Gass, S., \& Selinker, L. (2001). Second language acquisition: An introductory course (2nd ed.). Mahwah, NJ: Erlbaum.

Gebhard, M. (1999) Debates in SLA Studies: Redefining Classroom SLA as an Institutional Phenomenon. TESOL Quarterly, 33, 544-557. 
Genesee, F. (1985). Second language learning through immersion: A review of U.S. programs. Review of Educational Research, 55, 541-561.

Hammersley, M., \& Atkinson, P. (1995). Ethnography: Principles in practice (2nd ed.). London: Routledge.

Haneda, M., \& Wells, G. (2000). Writing in knowledgebuilding communities. Research in the Teaching of English, 34, 430-457.

Harris, R. (1999). Rethinking the bilingual learner. In A.Turo, C. Leung, \& C. Cable (Eds.), Rethinking Language Education (pp. 67-81). London: CILT.

Hatch, E. (1992). Discourse and language education. Cambridge: Cambridge University Press.

Hayes, R. (2005). Conversation, negotiation, and the word as deed: Linguistic interaction in a dual language program. Linguistics and Education, 16, 93-112.

Heller, M. (1999). Linguistic minorities and modernity: A sociolinguistic ethnography. Harlow, UK: AddisonWesley Longman.

Howard, E. R., \& Sugarman, J. (2007). Realizing the vision of two-way immersion: Fostering effective programs and classrooms. Washington, DC/McHenry, IL: Center for Applied Linguistics/Delta Systems, Co.

Howard, E. R., Sugarman, J., \& Christian, D. (2003). Trends in two-way immersion education: A review of the research (Rep. No. 63). Baltimore, MD: Center for Research on the Education of Students Placed At Risk.

Howard, E. R., Sugarman, J., Christian, D., LindholmLeary, K., \& Rogers, D. (2007). Guiding principles for dual language education (2nd ed.). Washington, DC: Center for Applied Linguistics.

Keck, C. M., Iberri-Shea, G., Tracy-Ventura, N., \& WaMbaleka, S. (2006). Investigating the empirical link between task-based interaction and acquisition: A meta-analysis. In J. Norris \& L. Ortega (Eds.), Synthesizing research on language learning and teaching (pp. 91-131). Philadelphia: Benjamins.

Krashen, S. D. (1985). The input hypothesis: Issues and implications. New York: Longman.

Lantolf, J. P. (2000). Sociocultural theory and second language learning. Oxford: Oxford University Press.

Lantolf, J. P. (2006). Re(de)fining language proficiency in light of the concept of "languaculture." In $\mathrm{H}$. Byrnes (Ed.), Advanced language learning: The contribution of Halliday and Vygotsky (pp. 72-91). London: Continuum.

Lapkin, S., Swain, M., \& Smith, M. (2002). Reformulation and the learning of French pronominal verbs in a Canadian French immersion context. Modern Language Journal, 86, 485-507.

Lave, J., \& Wenger, E. (1991). Situated learning: Legitimate peripheral participation. Cambridge: Cambridge University Press.

Lee, J. S., Bonnet-Hill, L., \& Gillespie, J. (2008) . Learning in two languages: Interactional space for becoming bilingual speakers. International Journal of Bilingual Education and Bilingualism, 11, 75-94.
Leung, C., Harris, R., \& Rampton, B. (1997). The idealized native speaker, reified ethnicities, and classroom realities. TESOL Quarterly, 31, 543-560.

Levine, G. S. (2003). Student and instructor beliefs and attitudes about target language use, first language use, and anxiety: Report of a questionnaire study. Modern Language Journal, 87, 343-364.

Lindholm-Leary, K. J. (2001) Dual language education. Clevedon, UK: Multilingual Matters.

Lindholm-Leary, K. J. (2004). The rich promise of twoway immersion. Educational Leadership, 62, 56-59.

Long, M. (1996). The role of linguistic environment in second language acquisition. In W. Ritchie \& T. Bhatia (Eds.), Handbook of second language acquisition (pp. 413-468). London: Academic Press.

Long, M., \& Porter, P. (1985). Group work, interlanguage talk, and second language acquisition. TESOL Quarterly, 19, 207-228.

Mackey, A. (2007). Conversational interaction in second language acquisition: A series of empirical studies. Oxford: Oxford University Press.

Mackey, A., Gass, S., \& McDonough, K. (2000). How do learners perceive interactional feedback? Studies in Second Language Acquisition, 22, 471-497.

Mackey, A., Oliver, R., \& Leeman, J. (2003). Interactional input and the incorporation of feedback: An exploration of NS-NNS and NNS-NNS adult and child dyads. Language Learning, 53, 35-66.

Martin-Beltrán, M. (2006) Opportunities for language exchange between language-minority and languagemajority students. Unpublished doctoral dissertation, Stanford University.

Martin-Beltrán, M. (March, 2007) Co-constructing competence and conditions for language exchange among language-minority and language-majority students. Paper prepared for the American Educational Research Association Conference, Chicago, IL.

Mayo, M. d. P. G. (2002). The effectiveness of two formfocused tasks in advanced EFL pedagogy. International Journal of Applied Linguistics, 12, 156175.

Miles, M., \& Huberman, A. M. (1994). Data management and analysis methods. In N. Denzin \& Y. Lincoln (Eds.), Handbook of qualitative research (pp. 428-444). Thousand Oaks, CA: Sage.

Moll, L. C., Amanti, C., Neff, D., \& González, N. (1992). Funds of knowledge for teaching: Using a qualitative approach to connect homes and classrooms. Theory into Practice, 31, 132-141.

Motha, S. (2006). Decolonizing ESOL: Negotiating linguistic power in U.S. public school classrooms. Critical Inquiry in Language Studies, 3, 75-100.

Negueruela, E., Lantolf, J. P., Jordan, S. R., \& Gelabert, J. (2004). The "private function" of gesture in second language speaking activity: A study of motion verbs and gesturing in English and Spanish. International Journal of Applied Linguistics, 14, 113-147.

Oliver, R. (2000). Age differences in negotiation and pairwork. Language Learning, 50, 119-151.

Pavlenko, A. (2000). L2 influence on L1 in late bilingualism. Issues in Applied Linguistics, 11, 175-206. 
Pica, T. (1994). Research on negotiation: What does it reveal about second-language learning conditions, processes, and outcomes? Language Learning, 44, 493-527.

Potowski, K. (2004). Student Spanish use and investment in a dual immersion classroom: Implications for second language acquisition and heritage language maintenance. Modern Language Journal, 88 , 75-101.

Rogoff, B. (1995). Observing sociocultural activity on three planes: Participatory appropriation, guided participation and apprenticeship. In J. Wertsch, P. Rio, \& A. Alvarez (Eds.), Sociocultural studies of the mind (pp. 139-164). Cambridge: Cambridge University Press.

Romaine, S. (1996). Bilingualism. In W. Ritchie \& T. Bhatia (Eds.), Handbook of Language Acquisition (pp. 571-604). New York: Academic Press.

Saunders, W., \& O’Brien, G. (2006). Oral language. In F. Genesse, K. Lindholm-Leary, W. Saunders, \& D. Christian (Eds.), Educating English language learners: A synthesis of research evidence (pp. 14-63). New York: Cambridge University Press.

Saussure, F. (1959). Course in general linguistics (W. Baskin, Trans.). New York: The Philosophical Library.

Scott, V., \& de la Fuente, M. J. (2008). What's the problem? L2 learners' use of the L1 during consciousness-raising, form-focused tasks. Modern Language Journal, 92, 100-113.

Storch, N. (2002) Patterns of interaction in ESL pair work. Language Learning, 52, 119-158.

Storch, N. (2008). Metatalk in a pair work activity: Level of engagement and implications for language development. Language Awareness, 17, 95114.

Storch, N., \& Wigglesworth, G. (2003). Is there a role for the use of the L1 in an L2 setting? TESOL Quarterly, 37, 760-770.

Swain, M. (1985). Communicative competence: Some roles of comprehensible input and comprehensible output in its development. In S. Gass \& C. Madden (Eds.), Input in second language acquisition (pp. 235-253). Rowley, MA: Newbury House.

Swain, M. (2000). The output hypothesis and beyond: Mediating acquisition through collaborative dialogue. In J. Lantolf (Ed.), Sociocultural theory and second language learning (pp.97-114). Oxford: Oxford University Press.

Swain, M. (2006). Languaging, agency and collaboration in advanced second language learning. In H. Byrnes (Ed.), Advanced language learning: The contribution of Halliday and Vygotsky (pp. 95-108). London: Continuum.

Swain, M., \& Deters, P. (2007). "New" mainstream SLA theory: Expanded and enriched. Modern Language Journal, 91, 820-836.

Swain, M., Brooks, L., \& Tocalli-Beller, A. (2002). Peerpeer dialogue as a means of second language learning. Annual Review of Applied Linguistics, 22, 171-185.
Swain, M., \& Lapkin, S. (1998). Interaction and second language learning: Two adolescent French immersion students working together. Modern Language Journal, 82, 320-337.

Swain, M., \& Lapkin, S. (2000). Task-based second language learning: The uses of the first language. Language Teaching Research, 4, 251-274.

Swain, M., \& Lapkin, S. (2002). Talking it through: Two French immersion learners' response to reformulation. International Journal of Educational Research, 37, 285-304.

Thomas, W., \& Collier, V. (2002). A national study of school effectiveness for language minority students' long-term academic achievement. Santa Cruz, CA: Center for Research on Education, Diversity \& Excellence.

Thorne, S. L., \& Lantolf, J. P. (2007). A linguistics of communicative activity. In S. Makoni \& A. Pennycook (Eds.), Disinventing and reconstituting languages (pp. 170-195). Clevedon, UK: Multilingual Matters.

Tocalli-Beller, A., \& Swain, M. (2007). Riddles and puns in the ESL classroom: Adults talk to learn. In A. Mackey (Ed.), Conversational interaction in second language acquisition: Empirical studies (pp. 143167). Oxford: Oxford University Press.

Valdés, G. (1997). Dual-language immersion programs: A cautionary note concerning the education of language-minority students. Harvard Educational Review, 67, 391-429.

Valdés, G. (2001). Learning and note learning English: Latino students in American schools. New York: Teachers College Press.

Valdés, G. (2003). Expanding definitions of giftedness: Young interpreters of immigrant background. Mahwah, NJ: Erlbaum.

Valdés, G. (2005). Bilingualism, heritage language learners, and SLA research: Opportunities lost or seized? Modern Language Journal, 89, 410434.

van Lier, L. (2000). From input to affordance: Socialinteractive learning from an ecological perspective. In J. Lantolf (Ed.), Sociocultural theory and second language learning (pp. 245-259). Oxford: Oxford University Press.

Vygotsky, L. (1978). Mind in society. Cambridge, MA: Harvard University Press.

Wei, L. (2000). The bilingualism reader. London: Routledge.

Wells, G. (1999). Using L1 to master L2: A response to Antón and DiCamilla's "Socio-cognitive functions of L1 collaborative interaction in the L2 classroom.” Modern Language Journal, 83, 248-254.

Wertsch, J. (1998). Mind as action. Oxford: Oxford University Press.

Yoon, B. (2008). Uninvited guests: The influence of teachers' roles and pedagogies on the positioning of English language learners in the regular classroom. American Educational Research Journal, 45, 495-522.

Zentella, A. C. (1997). Growing up bilingual: Puerto Rican children in New York. Malden, MA: Blackwell. 


\section{APPENDIX}

Transcription Conventions

\begin{tabular}{ll}
\hline [square brackets] & actions, comments and context \\
@@ & laughter, roughly use @ for each syllable \\
:: double colon & overlapping speech (included only where significant) \\
dash- & truncated word (sudden cutoff) \\
"double quotes" & $\begin{array}{l}\text { indicates code switching (i.e., use "español" during English LOI or usar "English" } \\
\text { durante clase de español) }\end{array}$ \\
'single quote' & $\begin{array}{l}\text { participants indicate written language } \\
\text { rising intonation (indicating question) }\end{array}$ \\
$!$ & exclamatory intonation \\
underline & word emphasized by speaker \\
italics & translation/gloss of original text \\
CAPS & indicates shouting or raised volume of speaker \\
xx & unintelligible words \\
(\# seconds) & pause \\
Bold type & highlighted for analytical purposes \\
\end{tabular}

Note. Excerpts are taken from larger transcriptions of student interactions. Line numbers are not from original transcripts. They are renumbered here. 